\title{
SULPHURIC ACID SCARIFICATION EFFECTS ON Brachiaria brizantha, B. humidicola AND Panicum maximum SEED DORMANCY RELEASE ${ }^{1}$
}

\author{
ROBERTOUSBERTI², LEILAMARTINS $^{3}$
}

\begin{abstract}
Most tropical forage grass species have dormant seeds, which reduce percentages in germination tests. The objective of this study was to evaluate $\mathrm{H}_{2} \mathrm{SO}_{4}$ scarification effects on seed dormancy releasing, through germination time $\left(\mathrm{T}_{50}\right)$ and variability among germination test replicates, in 630, 94 and 82 seed samples of B. brizantha, B. humidicola and P. maximum, respectively, tested at the Central Seed Testing Laboratory, Campinas, Brazil, from 1991 to 1999. Germination tests used two 4 x 100 replicates of intact and scarified seeds (15-, 10-, 5-minute treatments, respectively). Mean germination time $\left(\mathrm{T}_{50}\right)$ and variability among germination replicates were also analysed. Statistical analysis was performed by t-test paired samples for means. Scarification promoted general decreases in $\mathrm{T}_{50}$, while variability among germination test replicates was reduced in B. brizantha. Scarification increase germination in B. brizantha and P. maximum, but is deleterious in B. humidicola.
\end{abstract}

Index terms: forage grass species, mean germination time, variability among germination test replicates.

\author{
EFEITOS DA ESCARIFICAÇÃOCOM ÁCIDO SULFÚRICO NA LIBERAÇÃODA \\ DORMÊNCIA DE SEMENTES DE Brachiaria brizantha, B. humidicola AND Panicum \\ maximum.
}

\begin{abstract}
RESUMO - A maioria das gramíneas forrageiras tropicais apresenta dormência de sementes, que reduz as porcentagens obtidas nos testes de germinação. O objetivo deste trabalho foi avaliar os efeitos da escarificação com $\mathrm{H}_{2} \mathrm{SO}$ na liberação da dormência dessas sementes, no tempo médio de germinação $\left(T_{50}\right)$ e na variabilidade entre as repetições do teste de germinação. Para tanto foram analisadas 630, 94 e 82 amostras de sementes de B. brizantha, B. humidicola e P. maximum, respectivamente, recebidas no Laboratório Central de Sementes, Campinas, Brasil, no período de 1991 a 1999. Para os testes de germinação foram usados dois grupos de 4 x 100 repetições de sementes intactas e escarificadas (permanência no ácido durante 15, 10 e 5 minutos, respectivamente). Foram também analisados o tempo médio de germinação $\left(T_{50}\right)$ e a variabilidade entre as repetições do teste de germinação. A análise estatística foi executada através do teste $t$ para as médias de amostras pareadas. A escarificação promoveu decréscimos generalizados para $T_{50}$, enquanto a variabilidade entre as repetições dos testes de germinação foi reduzida em $B$. brizantha. A escarificação aumentaa germinação em $B$. brizantha e P. maximum, mas é deletéria em B. humidicola.
\end{abstract}

Termos para indexação: sementes de forrageiras, tempo médio de germinação, variabilidade entre as repetições do teste de germinação.

\footnotetext{
${ }^{1}$ Submited in 20/03/2006. Accept in 27/02/2007. Highlights were oralpresented at Session 6, 27 ${ }^{\text {th }}$ ISTA Congress, Budapest, Hungary, May 2004.

${ }^{2}$ Agronomist, PhD, Plant Protection Agency, P.O. Box 960, CEP 13.073-
}

001, Campinas, Brazil. usberti@cati.sp.gov.br. Corresponding author.

${ }^{3}$ Agronomist, Dr., Central Seed Testing Laboratory, P.O. Box 962, CEP 13.070-178, Campinas, Brazil. leila@cati.sp.gov.br 


\section{INTRODUCTION}

Fast and synchronised germination is highly desirable to set successfully forage grass pastures as well as to reduce the hazardous effects of weed species competition during the first stages of seed germination. Nevertheless, most of the cultivated tropical forage grass species have low seed germination and variable seedling emergence periods.

Seed dormancy shows a broad occurrence in these species and delays germination after sowing, thus exposing them to adverse conditions on many occasions (Herrera, 1994). High seed dormancy levels could prevent success in pasture establishment, thus delaying the genetic improvement due to an increase in the time required for selection cycles and evaluation studies (Voight and Tischler, 1997).

Brachiaria decumbens Stapf (signal grass) and $B$. humidicola (Rendle) Schweick (creeping signal grass) were introduced to Central Brazil in the 1960s because they presented better adaptation to the sandy, acid and naturally low fertile soils of the area; however, they have shown low production of green forage and dry matter as well as low nutritional value, and are also preferential host of the pest Deois fravopicta (Usberti Jr., 1993).

As a consequence, they were replaced in 1983 by $B$. brizantha (Hochst. ex A.Rich) Stapf (palisade grass), which shows high productive potential and relative tolerance to that pest, but it requires highly fertile soils. Nowadays, the main species of the genus used to set pasture fields in Brazil are $B$. brizantha, in the Central and Northern areas and B. humidicola, in the Northern area (Castro et al., 1994).

The Brachiaria genus presents a double seed dormancy mechanism, more pronounced in freshly harvested seeds, therefore germination percentage results are always lower than viability percentages achieved through the Tetrazolium test. In $B$. decumbens there is a variable primary dormancy in fresh seeds and a long-term dormancy due to mechanical seed coat restriction to oxygen diffusion, by the closely oppressed, hard, shiny palea and lemma structures enclosing the caryopsis (Whiteman and Mendra, 1982).

Guineagrass (Panicum maximum Jacq.) is a forage grass species with a broad application to set pasture fields in tropical climates, mainly on medium and highly fertile soils, and is a variable species, including many morphologic types. Most of the domesticated and established genotypes show low germination in the laboratory and seed quality is frequently low due to uneven maturation, seed shattering and seed dormancy (Harty et al., 1983). Seed dormancy in the species is based mainly on physical constraints, due to a lock-like structure fixing lemma and palea together (Who et al., 1991).

The tropical grass forage seed industry is characterised by gross fluctuations in supply, demand and price (Rains et al., 1993). Trading of these seeds is highly competitive and based mainly on lot agronomic value, which is a direct function of physical purity and germination percentage values. So, the success of trading and sowing operations is highly dependent on the previous knowledge of standard germination, physical purity and viability percentages.

Several methods have been tested aiming to release seed dormancy in those forage grass species, especially sulphuric acid scarification, as reported in B. brizantha (Montorio et al., 1997; Lago and Martins, 1998), in B. humidicola (Rodrigues et al., 1986; Macedo et al., 1994) and in Panicum maximum (Smith, 1979; Usberti et al., 2000).

The objective of this study was to evaluate the effects of sulphuric acid scarification on seed dormancy release, mean germination time $\left(\mathrm{T}_{50}\right)$ and variability among germination test replicates in seed samples of $B$. brizantha, B. humidicola and P. maximum.

\section{MATERIALAND METHODS}

This study was carried out at the Central Seed Testing Laboratory in Campinas, Brazil using 630 seed samples of $B$. brizantha cv. Marandu, 94 of B. humidicola cv. Common and 82 of Panicum maximum cv. Tobiata. Intact and scarified seeds were used. Figure 1 shows the germination percentages of these seeds. Seed samples were stored in a drying room $\left(15^{\circ} \mathrm{C} ; 40 \% \mathrm{RH}\right)$ before tests, presenting a water activity value $\left(\mathrm{A}_{\mathrm{w}}\right)$ of around 0.6.

Chemical scarification was made by immersing 4 x 100 replicates for each seed sample in a beaker with sulphuric acid $(96 \%, 36 \mathrm{~N})$ for 15, 10 and 5 minutes for B. brizantha, B. humidicola and P. maximum, respectively, stirring with a glass rod; after acid draining, the seeds were soaked in water for one hour followed by one minute-washing in running tap water and surface dried with blotting paper (Smith, 1979; ISTA, 2004).

Germination tests were performed using two 4 x 100 replicates of intact and scarified seeds, placed in square plastic boxes $(11 \times 11 \mathrm{~cm})$ over a sheet of filter paper moistened with $\mathrm{KNO}_{3}$ solution (0.2\%); afterwards they were kept in incubators under a $20-35^{\circ} \mathrm{C}$-alternating-diurnal-temperature regime (16 and 8 hours, with white light at $35^{\circ} \mathrm{C}$ ), with seedling counts made at 7, 14 and 21 days (B. brizantha and $B$. 


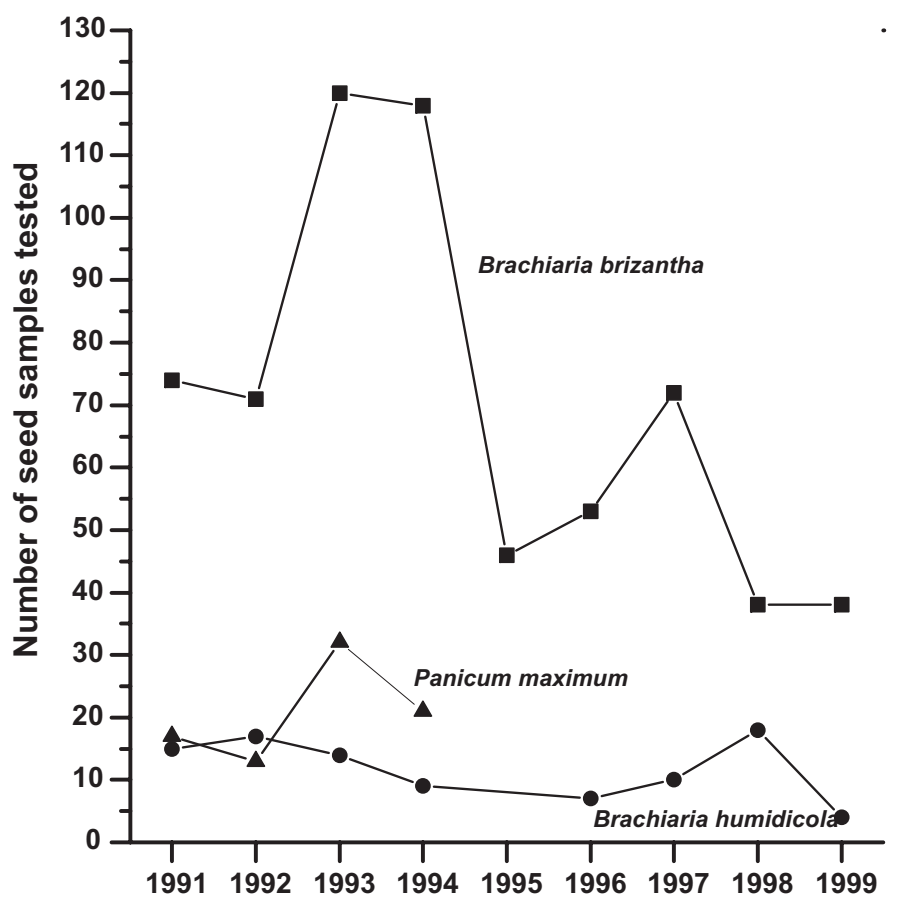

FIGURE 1. Forage grass seed samples tested at the Central Seed Testing Laboratory, Campinas, Brazil, from 1991 to 1999.

humidicola) and at 7, 14, 21 and 28 days ( $P$. maximum). Seedlings were evaluated according to the criterion of normal germination (ISTA, 2004).

The t-test paired samples for means, at $p<0.05$, was used for statistical analysis, with the previous transformation of final germination and replicate percentage values to arcsine

$\sqrt{\% / 100}$ (Sokal and Rohlf, 1969).

Mean germination time was calculated according to: , whereXi = number of newly germinated seeds at time Ti; the time used was the midpoint of the interval since the previous count. However, the time factor was $\log _{10}$ transformed, in order to normalise variance distribution (Alvarado and Bradford, 1988).

\section{RESULTS AND DISCUSSION}

Sulphuric acid scarification reduced mean germination times $\left(T_{50}\right)$ in the three forage grass species and the lowest results were recorded for $B$. brizantha (Figure 2). This effect was probably due to the highly desiccant effect of the acid on the seed coat, that allowed easier water uptake and oxygen diffusion (Smith, 1971; Montorio et al., 1997).

Similar results have been reported in other forage grass

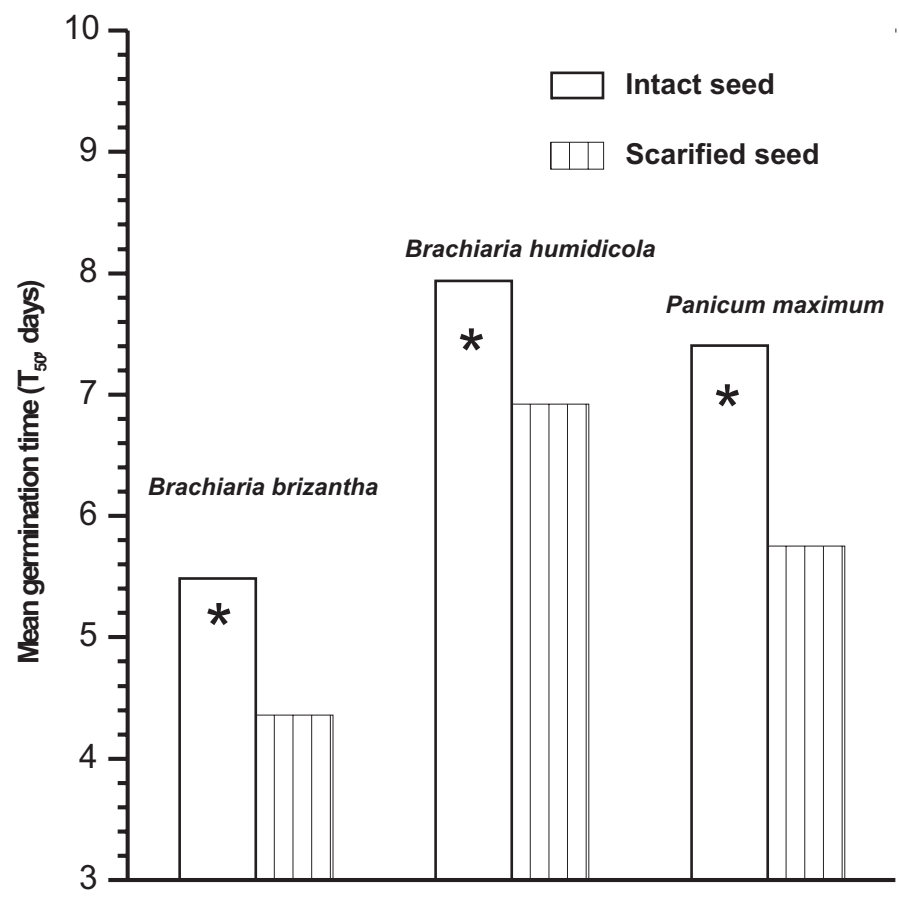

The symbol * shows statistical difference at $p<0.05$

FIGURE 2. Mean germination time $\left(T_{50}\right)$ values recorded in forage grass seed samples tested at the Central Seed Testing Laboratory from 1991 to 1999.

species. Tischler et al. (1994), analysing the effects of sulphuric acid and chloroethanol in switchgrass (Panicum virgatum) seed dormancy release, verified that a 10 -minute treatment was the most effective method in increasing final and germination rate. Voight and Tischler (1997) verified that 5-, 10- and 15-minute sulphuric acid treatments increased final and seed germination rate in kleingrass (Panicum coloratum). Usberti and Valio (1997) reported that sulphuric acid scarification had a remarkable effect on increasing the speed and final seed germination percentage in guineagrass. Martins and Silva (2001) also verified that both high temperatures (above $70^{\circ} \mathrm{C}$ ) and sulphuric acid scarification significantly increased the seed emergence rate in $B$. brizantha.

Variability among seed germination replicates was reduced in $B$. brizantha after chemical scarification but remained unchanged in the other species, probably due to the different scarification periods applied for the three species (Figure 3). This issue has not been analysed in any related research papers, but was probably caused by nonhomogeneous seed lots due to uneven maturation and different seed dormancy levels, always present in forage grass species.

Sulphuric acid scarification produced a deleterious effect 


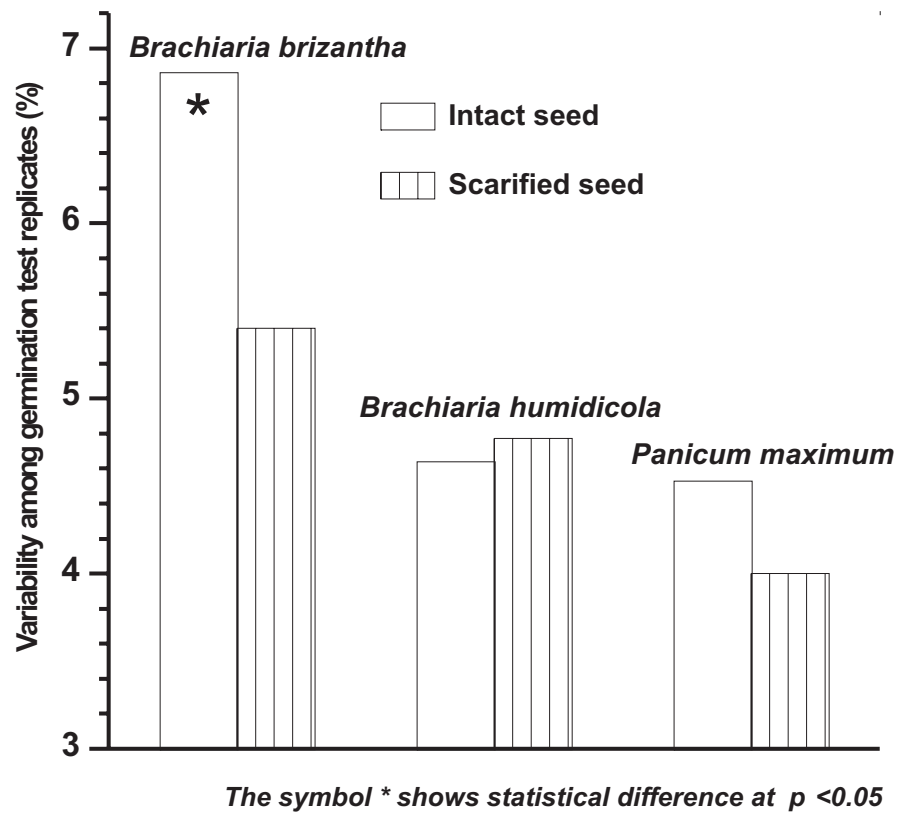

FIGURE 3. Variability among germination test replicate percentages in forage grass seed samples tested at the Central Seed Testing Laboratory from 1991 to 1999.

in $B$. humidicola, but improved seed germination percentages in $B$. brizantha and $P$. maximum, probably due its deleterious effect on germination being counterbalanced by higher seed dormancy release (Figure 4). Similar results have been reported in B. brizantha seeds, by using 15-minute (Montorio et al., 1997; Lago and Martins, 1998) and 20-minute treatments (Castro et al., 1994), in B. decumbens using 20-, 15- and 12minute treatments (Whiteman and Mendra, 1982; Usberti, 1990; Herrera, 1994) and with a 15-minute treatment in $B$. ruziziensis (Ruzi grass) (Mclean and Grof, 1968), as well as in a weed species, B. plantaginea (Alexander grass) (Freitas et al., 1990).

Sulphuric acid 5-minute treatment increased final seed germination percentages in P. maximum, as reported by Smith (1971) and Usberti (1981). However, Smith (1979), analysing nine genotypes of $P$. maximum presenting variable initial seed dormancy values, verified that the sulphuric acid 5-minute treatment led to different genotype responses. Moreover, Usberti et al. (2000), analysing 15 P. maximum hybrids ranked by flowering cycles, reported that the higher the flowering cycle, the lower the seed dormancy level. Therefore guineagrass seed quality indices are strongly affected by the genotype, thus explaining discrepant results reported in several published papers.

The harmful effect of sulphuric acid scarification has already been detected in $B$. humidicola by Rodrigues et al.

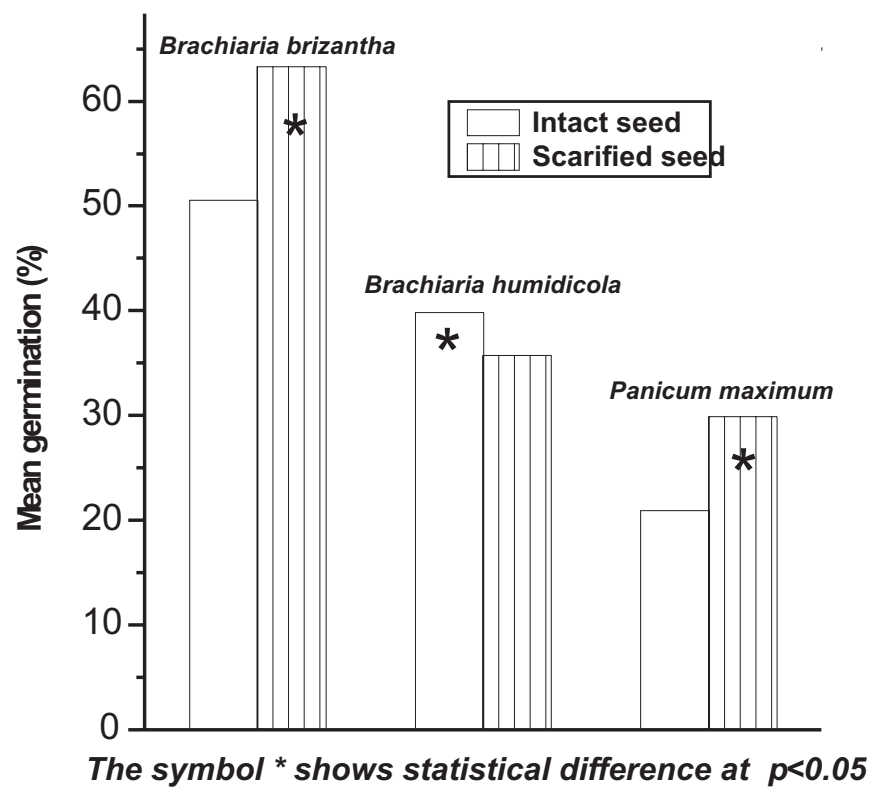

FIGURE 4. Mean germination percentage values recorded in forage grass seed samples tested at the Central Seed Testing Laboratory from 1991 to 1999.

(1986) and Macedo et al. (1994) (15- and 10-minute treatments, respectively) as well as in B. mutica (Para grass) using a 10-minute treatment (Mclean and Grof, 1968).

The hypothesis which relates the positive effect of $\mathrm{H}_{2} \mathrm{SO}_{4}$ scarification on seed dormancy release, through the removal of an endogenous growth inhibitor, was discarded by Usberti and Valio (1997) in Panicum maximum, showing that ABA levels remained unchanged after scarification.

Thus, it is quite evident that the main effects of sulphuric acid on seed dormancy release are closely related to both its strong desiccant effect and the high temperature generated by its application (Grof, 1968; Rodrigues et al., 1986). Thus, probably $\mathrm{H}_{2} \mathrm{SO}_{4}$ scarification in fact mimics the practice of setting fire to old pastures to renew the forage grass plant stand.

\section{CONCLUSION}

Sulphuric acid scarification is deleterious for $B$. humidicola seed longevity but improves rate and germination percentages in $B$. brizantha and $P$. maximum.

\section{REFERENCES}

ALVARADO, N.A.; BRADFORD, K.J. Priming and storage of tomato (Lycopersicon lycopersicum) seeds. I. Effects of storage 
temperature on germination rate and viability. Seed Science and Technology, Zürich, v.16, p.601-612, 1988.

CASTRO, C.R.T.; CARVALHO, W.L; REIS, F.P. Influência do tratamento com ácido sulfúrico na germinação de sementes de Brachiaria brizantha Stapf. Revista Ceres, Viçosa, v.41, p.451458, 1994

FREITAS, R.R.; CARVALHO, D.A.; ALVARENGA, A.A. Quebra da dormência e germinação de sementes de capim-marmelada (Brachiaria plantaginea (Link) Hitch). Brazilian Journal of Plant Physiology, São Carlos, v.2, p.31-35, 1990.

GROF, B. Viability of seed of Brachiaria decumbens. Queensland Journal of Agricultural and Animal Sciences, Brisbane, v.25, p.149-151, 1968.

HARTY, R.L.; HOPKINSON, J.M.; ENGLISH, B.H., ALDER, J. Germination, dormancy and longevity in stored seeds of Panicum maximum. Seed Science and Technology, Zürich, v.11, p.361-369, 1983.

HERRERA, J. Efecto de algunos tratamientos para interrumpir el reposo en semillas de pastos. II. Brachiaria decumbens. Agronomía Costarricense, San José, v.18, p.75-85, 1994.

INTERNATIONAL SEED TESTING ASSOCIATION. International rules for seed testing. Edition 2004. Bassersdorf, Switzerland, 2004. 410p.

LAGO, A.A.; MARTINS, L. Qualidade fisiológica de sementes de Brachiaria brizantha. Brazilian Journal of Agricultural Research, Brasília, v.33, p.299-204, 1998.

MACEDO, E.C.; GROTH, D.; LAGO, A.A. Efeito de escarificação com ácido sulfúrico na germinação de sementes de Brachiaria humidicola (Rendle) Schweick. Brazilian Journal of Agricultural Research, Brasília, v.29, p.455-460, 1994.

MARTINS, L.; SILVA, W.R. Comportamento da dormência em sementes de braquiária submetidas a tratamentos térmicos e químicos. Brazilian Journal of Agricultural Research, Brasília, v.36, p.997-1003, 2001.

MCLEAN, D.; GROF, B. Effect of seed treatments on Brachiaria mutica and B. ruziziensis. Queensland Journal of Agricultural and Animal Sciences, Brisbane, v.25, p.81-83, 1968.

MONTORIO, G.A.; BRACCINI, A.L.; SCAPIM, V.R.O.; BRACCINI, M.C.L. Avaliação de métodos para superação da dormência das sementes de capim braquiária (Brachiaria brizantha cv. Marandu). Revista Unimar, Marília, v.19, p.797-809, 1997.

RAINS, J.P.; HOPKINSON, J.M.; TREGEA, S.P. Tropical pasture establishment. 10. Satisfying industry's pasture seed requirements. Tropical Grasslands, Peak Crossing, v.27, p.359366, 1993.

RODRIGUES, J.D.; DELACHIAVE, M.H.A.; RODRIGUES, S.D.; PEDRAS, J.F.; GAETI, O.B.N. Efeitos de diferentes métodos para a quebra da dormência de sementes de Brachiaria humidicola (Rendle) Schweickerdt. Científica, São Paulo, v.14, p.65-72, 1986.

SMITH, C.J. Seed dormancy in Sabi Panicum. Proceedings of the International Seed Testing Association, Zürich, v.36, p.81-97, 1971.

SMITH, R.L. Seed dormancy in Panicum maximum Jacq. Tropical Agriculture, London, v.56, p.233-239, 1979.

SOKAL, R.R.; ROHLF, F.J. Biometry. San Francisco: Freeman and Company, 1969. 776p.

TISCHLER, C.R.; YOUNG, B.A.; SANDERSON, M.A. Techniques for reducing seed dormancy in switchgrass. Seed Science and Technology, Zürich, v.22, p.19-26, 1994.

USBERTI Jr., J.A. Capim-colonião (Guineagrass). In: VIEGAS, G.P.; FURLANI, A.M.C. (Ed.). Melhoramento de Plantas no Instituto Agronômico de Campinas. Campinas: IAC, 1993. p.95-109.

USBERTI, R. Nova metodologia para o teste de germinação de sementes de capim-colonião. Casa da Agricultura, Campinas, v.3, p.12-16, 1981.

USBERTI, R. Determinação do potencial de armazenamento de lotes de sementes de Brachiaria decumbens através do teste de envelhecimento acelerado. Brazilian Journal of Agricultural Research, Brasília, v.25, p.691-699, 1990.

USBERTI, R.; VALIO, I.F.M. Endogenous growth regulator detection in guinea grass seeds. Brazilian Journal of Agricultural Research, Brasília, v.32, p.695-700, 1997.

USBERTI, R.; USBERTI Jr., J.A.; PATERNIANI, R.S. Flowering cycle-related seed quality characteristics of 15 guineagrass (Panicum maximum Jacq.) hybrids. Seed Science and Technology, Zürich, v.28, p.437-443, 2000.

VOIGHT, P.W.; TISCHLER, C.R. Effect of seed treatment on germination and emergence of 3 warm-season grasses. Journal of Range Management, Lakewood, v.50, p.170-174, 1997.

WHITEMAN, P.C.; MENDRA, K. Effects of storage and seed treatments on germination of Brachiaria decumbens. Seed Science and Technology, Zürich, v.10, p.233-242, 1982.

WHO, E.; KUITERS, A.T.; TOLSMA, D.J. Dormancy of annual and perennial grasses from a savannah of southeastern Botswana. Acta Oecologica, Paris, v.12, p.727-739, 1991.

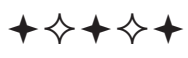

